\author{
Artur BARTOSIK ${ }^{1}$ \\ Agnieszka PIOTROWSKA-PIATTEK ${ }^{2}$ \\ Marta POMIETLORZ-LOSKA ${ }^{3}$
}

\title{
TSL SERVICES MARKET AS A SUPPORT SYSTEM OF THE POLISH ECONOMY
}

\begin{abstract}
Transport, Spedition and Logistics (TSL) are considered to be one of the main services markets of the Polish economy. The relationship between the development of the national economy and the development of the TSL services market is due to the fact that TSL is a carrier of the economy. Globalization, the development of information and communication technologies, and Polish accession to the European Union are factors favoring the development of this particular market. The purpose of the paper is to verify whether a change of selected variables in analyzed market affects general changes of the national economy in Poland. The defined objective was realized through the analysis of literature and research desk. The analysis of statistical data covers the period of 2004 to 2013. The theoretical part presents the scope and requirements of the development of the TSL services market. The empirical part conducts a retrospective analysis of the evolution of the variables that were considered relevant for analysis of TSL services market and identifies its importance to the national economy in Poland. The authors chose arbitrarily defined indicators whose impact on economic development they considered important: the number of companies, the number of employees, gross profit and participation in the GDP. It was found that in the analyzed period there were dynamic changes in the TSL services market. These changes reflect the fluctuations of the Polish economy - periods of economic recovery and recession, which confirms the assumption that the TSL services market can be treated as a carrier of a country's economy.
\end{abstract}

Keywords: TSL services market, carrier of economy, support system of economy

\section{INTRODUCTION}

Transport, Spedition and Logistics (TSL) are considered to be one of the key services markets of the Polish economy. The relationship between the development of the national economy and the development of the TSL services market is due to the fact that TSL is a carrier of the economy. Globalization, development of information and communication technologies, and Polish accession to the European Union are factors favoring the development of this particular market.

The objective of this paper is to verify whether a change of selected variables in TSL services market affects general changes of the national economy in Poland. In order to

\footnotetext{
${ }^{1}$ Artur Bartosik, Prof., DSc, PhD, Eng, Kielce University of Technology, Faculty of Management and Computer Modelling, Al. Tysiąclecia P.P.7, 25-314 Kielce, e-mail: artur.bartosik@tu.kielce.pl, tel.: +48 413424440.

${ }^{2}$ Agnieszka Piotrowska-Piątek, PhD, Statistical Office in Kielce 25-369, ul. Zygmunta Wróblewskiego 2, tel.: +48 4124996 00; e-mail: a.piotrowska-piątek@stat.gov.pl; Kielce University of Technology, Faculty of Management and Computer Modelling; Al. Tysiąclecia P.P.7, 25-314 Kielce (corresponding author).

${ }^{3}$ Marta Pomietlorz-Loska, MsC, Eng. University of Bielsko-Biala, Department of Production Engineering, email: marta.pomietlorz@wp.pl.
} 
achieve it, an analysis of the literature and desk research were done. The theoretical part presents the scope and requirements of the development of the TSL services market. The empirical part contains a retrospective analysis of the evolution of the variables that were considered relevant for analyzing TSL services market, and identifies its importance to the national economy in Poland.

\section{TSL SERVICES MARKET - THE SCOPE AND CONDITIONS OF THE DE- VELOPMENT}

Analyzing the TSL market in Poland, Szyszka recognized the following groups of companies providing services: transport and rail forwarding, transport and road forwarding, courier services, storage, transport and mixed forwarding ${ }^{4}$. Given the scope of the activities of the market, however, the TSL should be complemented by pipeline transport services, air and postal operations.

Before the presentation of the basic conditions for the development of the TSL market in Poland, it should be noted that while transport and storage services, as well as postal activities, were present in Poland also in the past, logistics services appeared only in the late 80 s of the twentieth century. The biggest development of the TSL sector followed the Polish accession to the EU, together with the abolition of barriers to movement of people and goods. This also resulted from the absorption of EU funds, which significantly contributed to the improvement in road infrastructure, both in terms of its quantity and quality.

Currently, the market for logistics services owes its growth to the increasing corporate decisions to outsource, undertaken as a result of optimizing supply and distribution systems. According to Grucki, the demand for logistics services, primarily from large manufacturers and retailers, should be seen as results of: technical complexity of the supply chain, due to higher requirements of manufacturing companies and retail networks; new requirements for the operation of integrated logistics chains that force demand for increasing financial resources to maintain an adequate level of service; globalization activities of manufacturing companies and retail chains; and the need to coordinate them on a global scale. $^{5}$

Grucki also notes that all the sources of growth in demand for logistics services are closely linked to each other and they come from two main features which are characteristic of modern logistics market: multi-level functions and area of geographical activities of enterprises and engineering solutions. It comes down to the fact that not only do logistics companies manage more plants or features, but also they have the ability to create logistics processes with customers ${ }^{6}$. As a result, determinants of the development of the analyzed market are related to both micro and macro scale.

\footnotetext{
${ }^{4}$ G. Szyszka, Logistyka w Polsce w latach 2006-2007, [in:] Logistics 2008. Nowe wyzwania-nowe rozwiazania, Instytut Logistyki i Magazynowania, Poznań 2008, p.25.

${ }^{5} \mathrm{~K}$. Grucki, Rynek ustug logistycznych, [in]: Logistyka w biznesie, M. Ciesielski (Ed.), Polskie Wydawnictwo Ekonomiczne, Warszawa 2006, pp. 213-214.

${ }^{6} \mathrm{~K}$. Grucki, Rynek ustug logistycznych, [in]: Logistyka w biznesie, M. Ciesielski (Ed.), Polskie Wydawnictwo Ekonomiczne, Warszawa 2006, pp. 213-214.
} 


\section{ANALYSIS OF THE TSL SERVICES MARKET IN POLAND IN 2004-2013}

The analysis of the TSL services market was carried out taking into account the data of the Central Statistical Office of Poland (GUS), related to the Transportation and Storage section (section H according to the Polish Classification of Activities 2007 - PKD 2007), covering the period of 2004-2013. ${ }^{7}$ This section is divided into: land and pipeline transports, water transport, air transport, warehousing and support activities for transportation, postal and courier activities. The study used the data on: the number of enterprises, the number of employees, gross financial result and contribution to GDP.

The number of companies in the Transportation and Storage section over the last ten years has been changing, which was caused by fluctuations of the Polish economy. It is also linked with the processes of consolidation and concentration of TSL market. As you can see in Fig. 1, we observe two periods in which the number of businesses reached the highest values, i.e. 2006-2008 and 2010-2012.These periods correspond to periods of a favorable situation in the Polish economy. A significant reduction in the number of TSL firms in 2009 was due to the economic crisis that began in the global banking market. It should also be noted that starting from 2012, we again observed a decrease in the number of TSL firms, which could mean a further economic slowdown.

Fig. 1. Changes in the number of enterprises in the Transportation and Storage section in Poland from 2004 to 2013

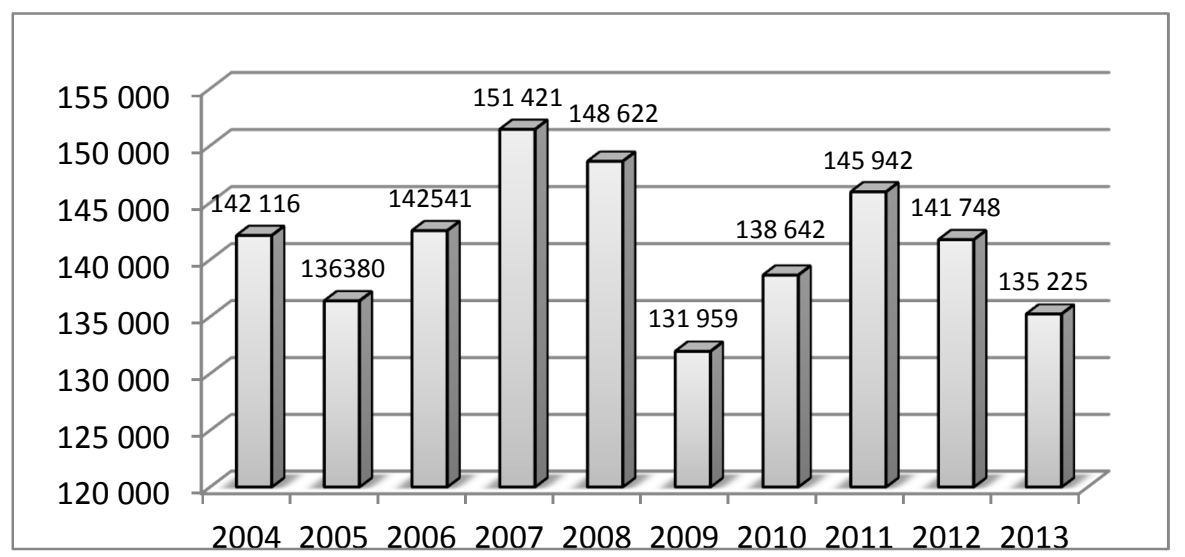

Source: Elaboratedusing GUS data.

Changes in the number of companies linked to the change in the number of employees. In view of the fact that in the analyzed period, as outlined above, there were significant changes in the number of enterprises, it is expected that this fact will result in changes in the number of employees. Detailed data are shown in Fig. 2.

\footnotetext{
${ }^{7}$ According to the fact that in the Polish Classification of Activities 2007 (PKD 2007) there isn 't a section of TSL services, it is assumed that TSL services are the closest to Section H Transportation and Storage; cf.: C. Mańkowski, Polski rynek ustug logistycznych wobec kryzysu gospodarczego w Unii Europejskiej, "Prace I Materiały Instytutu Handlu Zagranicznego Uniwersytetu Gdańskiego" 2012 nr 31/2, p. 214.
} 
Fig. 2. Changes in the number of employees in the Transportation and Storage section in Poland from 2004 to 2013

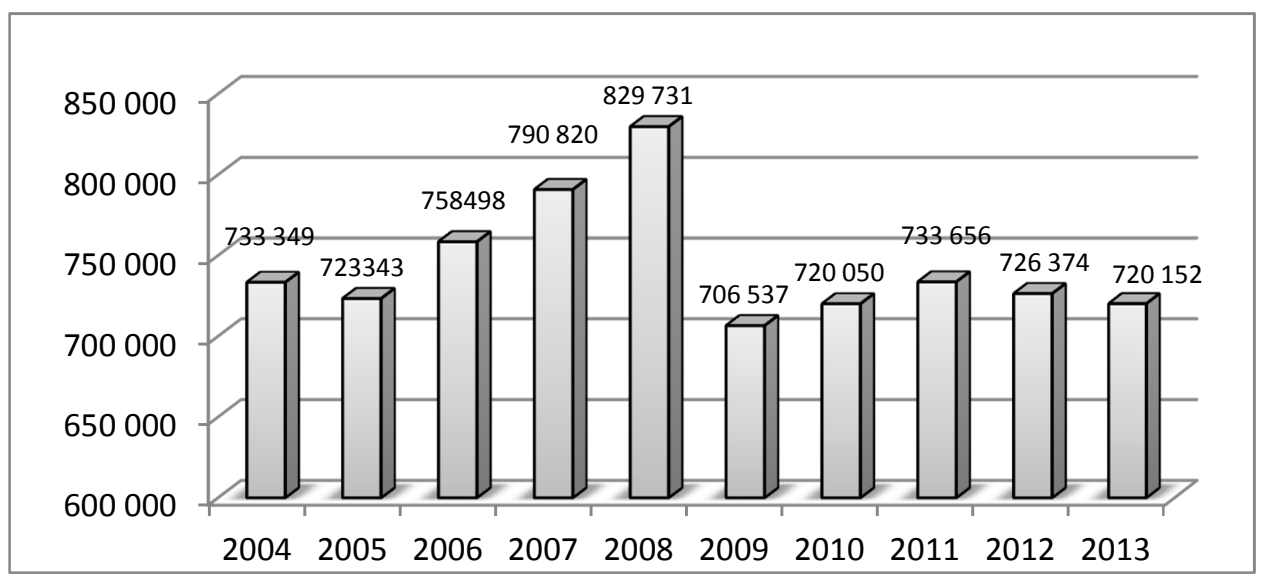

Source: Elaborated using GUS data.

In order to determine the share of the analyzed section in the labor market in Poland, Figure 3 shows the percentage of the number of people working in this section in relation to the total number of employees in Poland. The largest decline in the number of employees in the Transportation and Storage section was observed in 2009, which was due to a significant decrease in the number of enterprises.

Fig. 3 Contribution of the Transportation and Storage section to labour market in Poland in from 2004 to 2013

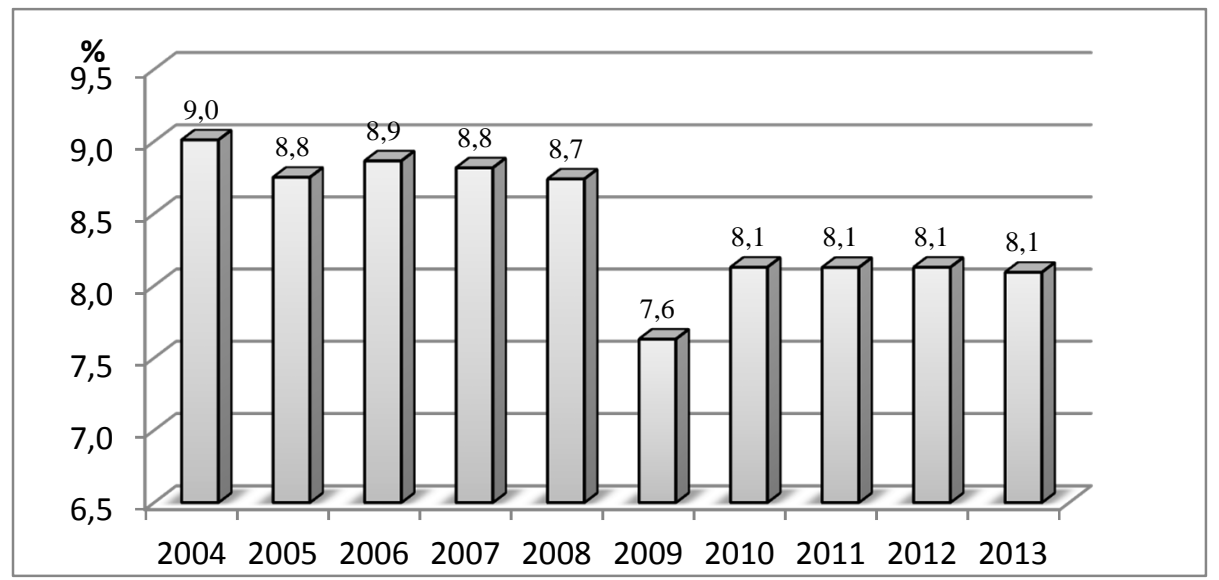

Source: Elaborated using GUS data.

As profit is one of the basic measures of economic evaluation of the company, the gross profit of companies in Section $\mathrm{H}$ was analyzed. As seen in Table 1, the best results 
in terms of profit in this section were achieved in 2006 and 2007. It was a period in which sales revenue grew at a faster rate than the cost of revenue. The lowest gross profit was observed in 2008, which was due to the fact that the cost of revenue grew faster than the total revenue, including the deterioration in the results on financial operations. High rates of growth on the basis of this variable in the following years were caused by the very low value of the base in 2008 .

Table 1. Dynamic indicators of gross profit in the Transportation and Storage section in Poland in $2004-2013^{8}$

\begin{tabular}{|l|r|r|r|}
\hline \multicolumn{1}{|c|}{ Years } & $\begin{array}{c}\text { Gross profit } \\
\text { (billion PLN) }\end{array}$ & $\begin{array}{c}\text { Single base index } \\
(2004=100)\end{array}$ & $\begin{array}{c}\text { Chain index } \\
\text { (previous year = 100) }\end{array}$ \\
\hline 2004 & 3182,7 & 100 & 32,2 \\
\hline 2005 & 1025,3 & 32,2 & 303,1 \\
\hline 2006 & 3107,5 & 97,6 & 120,3 \\
\hline 2007 & 3738,7 & 117,5 & 16,2 \\
\hline 2008 & 605,5 & 19,0 & 174,1 \\
\hline 2009 & 1053,9 & 33,1 & 104,9 \\
\hline 2010 & 1823,1 & 57,3 & 112,9 \\
\hline 2011 & 1913,0 & 60,1 & 125,1 \\
\hline 2012 & 2158,9 & 67,8 & 84,9 \\
\hline 2013 & 2701,1 & & \\
\hline
\end{tabular}

Source: elaborated using GUS data.

\section{IMPORTANCE OF THE TSL SERVICES MARKET TO THE POLISH ECONOMY}

In the literature there is a consensus that the rate of growth of the national economy is relevant to changes in transport, spedition and logistics. Logistics constitutes an important element of the economic system, which enables smooth functioning of the national economy ${ }^{9}$. The importance of transport for the national economy is due to its multilateral links between all forms of business, manufacturing, cultural, and settlement activities. This results from needs which may be satisfied just by transport ${ }^{10}$.

Research on the global economy, taking China as an example, shows relationship between logistics development and economic growth in both short and long term perspec-

\footnotetext{
${ }^{8}$ data regard entities which employed more than 49 people.

${ }^{9}$ I. Fechner, G. Szyszka (Eds.), Logistyka w Polsce. Raport 2007, Instytut Logistyki i Magazynowania, Poznań 2008, p.15.

${ }^{10} \mathrm{M}$. Mindur, Wzajemne zwiazki i zależności między rozwojem gospodarki a transportem, Wydawnictwo Instytutu Technologii Eksploatacji, Warszawa 2004, p. 139.
} 
tive $^{11}$. Often, therefore, TSL services market is defined as so-called support system of economy or carrier of economy that allows development of other areas, such as trade and other services for the population.

Analysis of the TSL services market development in European countries shows that productivity of this market can be higher comparing to the total economy. For example, Langviniene and Sliziene stated that in Lithuania $7 \%$ of employees worked in the transport and logistics services and they created 13\% of GDP in 2013 ${ }^{12}$. In Poland, as shown in Figure 4, there is more than 6\% of the section's share in GDP before 2010 and we observe a decrease to about $5 \%$ from 2010.

Fig. 4. The share of the Transportation and Storage section in the GDP of Poland from 2004 to 2013

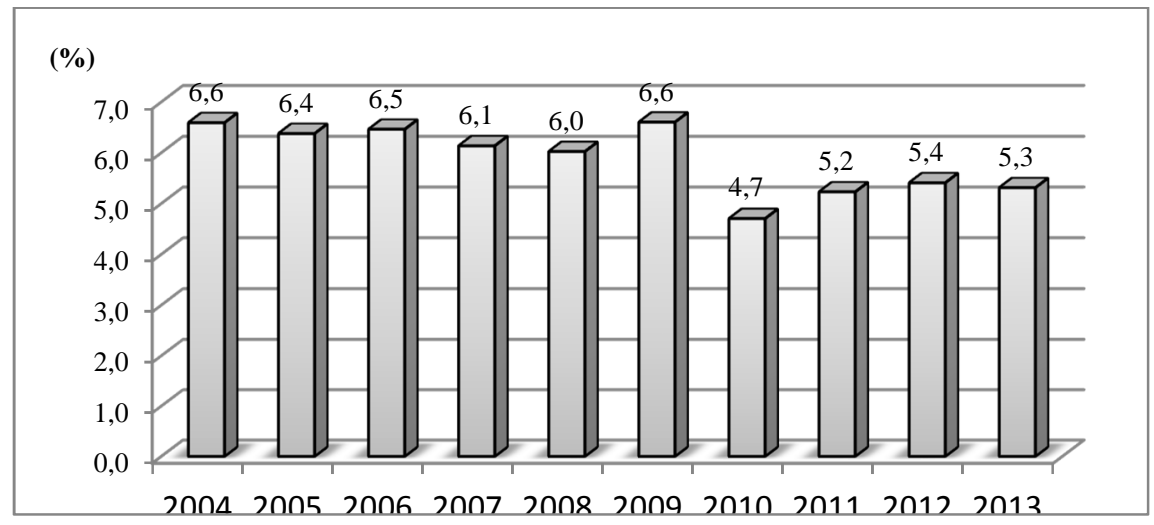

Source: Elaborated using GUS data.

\section{SUMMARY}

In the light of the desk research presented above, in the period from 2004 to 2013 we observed dynamic changes in section $\mathrm{H}$ in Poland in terms of the number of enterprises, the number of employees, gross profit and contribution to GDP. These changes reflect fluctuations of the Polish economy - periods of recovery and economic down turn, which confirms the assumption made in the paper about the carrying capacity of the TSL services market for the economic system of the country.

It seems that at present the biggest challenges for the analyzed market are an increasingly diverse customer expectation (particularly institutional) and the need to increase economic efficiency. The first of these factors is related to the four fundamental trends characteristic of modern enterprises operating activities: transition from the transaction to the process and network, application of information technology, transition from regional

\footnotetext{
${ }^{11}$ H.H. Lean,W. Huang, J. Hong, Logistics and economic development: Experience form China, "Transport Policy", 2014/32.

${ }^{12} \mathrm{~N}$. Langviniene,G. Sliziene, Management of sustainable transport and logistics services sector`s growth in the context of Lithuanian economic development, "Proceedia of Social and Behavioral Sciences", 2014/156, p. 19.
} 
business to business network, changes in business operation strategies from push to pull. ${ }^{13}$

It should be noted that the above-mentioned factors influence the TSL services market development. Thus, they constitute a chance in attracting new customers, both in terms of geographic expansion and the market. On the other hand, these factors constitute a significant challenge to this market. Rucińska recognizes that the buyers of the TSL services clearly formulate demands with regard to operators expecting personalized, flexible services of high standards ${ }^{14}$. These factors are also related to the need to increase economic efficiency in this market.

\section{REFERENCES}

[1] Fechner, G. Szyszka (Eds.), Logistyka w Polsce. Raport 2007, Instytut Logistyki i Magazynowania, Poznań 2008

[2] GUS, Działalność przedsiębiorstw niefinansowych w 2004r., ZWS, Warszawa 2005

[3] GUS, Transport - wyniki działalności w 2004r., ZWS, Warszawa 2005

[4] GUS, Działalność przedsiębiorstw niefinansowych w 2005r., ZWS, Warszawa 2006

[5] GUS, Transport - wyniki działalności w 2005r., ZWS, Warszawa 2006

[6] GUS, Dziatalność przedsiębiorstw niefinansowych w 2006r., ZWS, Warszawa 2007

[7] GUS, Transport - wyniki działalności w 2006r., ZWS, Warszawa 2007

[8] GUS, Działalność przedsiębiorstw niefinansowych w 2007r., ZWS, Warszawa 2008

[9] GUS, Transport - wyniki działalności w 2007r., ZWS, Warszawa 2008

[10] GUS, Działalność przedsiębiorstw niefinansowych w 2008r., ZWS, Warszawa 2009

[11] GUS, Transport - wyniki działalności w 2008r., ZWS, Warszawa 2009

[12] GUS, Działalność przedsiębiorstw niefinansowych w 2009r., ZWS, Warszawa 2010

[13] GUS, Transport - wyniki działalności w 2009r., ZWS, Warszawa 2010

[14] GUS, Działalność przedsiębiorstw niefinansowych w 2010r., ZWS, Warszawa 2011

[15] GUS, Transport - wyniki działalności w 2010 r., ZWS, Warszawa 2011

[16] GUS, Działalność przedsiębiorstw niefinansowych w 2011r., ZWS, Warszawa 2012

[17] GUS, Transport - wyniki działalności w 2011r., ZWS, Warszawa 2012

[18] GUS, Działalność przedsiębiorstw niefinansowych w 2012r., ZWS, Warszawa 2013

[19] GUS, Transport - wyniki działalności w 2012r., ZWS, Warszawa 2013

[20] GUS, Działalność przedsiębiorstw niefinansowych w 2013r., ZWS, Warszawa 2014

[21] GUS, Transport - wyniki działalności w 2013r., ZWS, Warszawa 2014

[22] K. Grucki, Rynek ustug logistycznych, [in:] M. Ciesielski (Ed.), Logistyka w biznesie, Polskie Wydawnictwo Ekonomiczne, Warszawa 2006

[23] H.H. Lean, W. Huang, J. Hong, Logistics and economic development: Experience form China, "Transport Policy", 2014/32

[24] N. Langviniene, G. Sliziene, Management of sustainable transport and logistics services sector's growth in the context of Lithuanian economic development, "Proceedia of Social and Behavioral Sciences", 2014/156

[25] C. Mańkowski, Polski rynek ustug logistycznych wobec kryzysu gospodarczego w Unii Europejskiej, "Prace i Materiały Instytutu Handlu Zagranicznego Uniwersytetu Gdańskiego" 2012 nr 31/2

\footnotetext{
${ }^{13}$ K. Grucki, Rynek ustug logistycznych, [in:] M. Ciesielski (Ed.), Logistyka $w$ biznesie, Polskie Wydawnictwo Ekonomiczne, Warszawa 2006, pp. 213-214.

${ }^{14}$ D.Rucińska, Strategiczne aspekty kształtowania polskiego rynku usług transportowo -spedycyjno - logistycznych, www.pte.pl/kongres/referaty/dirRuciskaDanuta, (data dostępu: 2015.02.07), p. 15.
} 
[26] M. Mindur, Wzajemne związki i zależności między rozwojem gospodarki a transportem, Wydawnictwo Instytutu Technologii Eksploatacji, Warszawa 2004

[27] D. Rucińska, Strategiczne aspekty kształtowania polskiego rynku usług transportowo - spedycyjno - logistycznych (TSL), www.pte.pl/kongres/referaty/dirRuciskaDanuta

[28] G. Szyszka, Logistyka w Polsce w latach 2006-2007, [in:] Logistics 2008. Nowe wyzwania-nowe rozwiazania, Instytut Logistyki i Magazynowania, Poznań 2008

\section{RYNEK USŁUG TSL JAKO SYSTEM NOŚNY POLSKIEJ GOSPODARKI}

Transport, spedycja i logistyka (TSL) są uważane za jeden z kluczowych rynków usługowych polskiej gospodarki. Związek pomiędzy rozwojem gospodarki narodowej a rozwojem rynku TSL wynika $\mathrm{z}$ faktu, że pełni on rolę systemu nośnego, świadczącego usługi dla pozostałych sektorów gospodarki. Czynnikami szczególnie sprzyjającymi rozwojowi tej branży są globalizacja, rozwój technologii informacyjno-komunikacyjnych oraz akcesja Polski do struktur Unii Europejskiej. Celem artykułu jest weryfikacja wpływu wybranych zmiennych dotyczących rynku usług TSL na ogólne zmiany w gospodarce w Polsce. Dla jego realizacji przeprowadzono analizę literatury przedmiotu oraz badania typu desk research. Analiza danych statystycznych objęła szereg czasowy 2004-2013. W teoretycznej części artykułu przedstawiono zakres i uwarunkowania rozwojowe analizowanego rynku. W części empirycznej przeanalizowano zmienne, które uznano za istotne w rozwoju rynku usług TSL i jego znaczenia dla gospodarki krajowej, tj.: liczbę przedsiębiorstw, liczbę pracujących, wynik finansowy oraz udział w PKB. W świetle zaprezentowanych wyników zaobserwowano dynamiczne zmiany na rynku usług TSL w Polsce w zakresie analizowanych zmiennych. Zmiany te odzwierciedlają wahania kondycji polskiej gospodarki - okresy ożywienia i dekoniunktury gospodarczej, co potwierdza założenie o nośnym charakterze usług TSL dla gospodarki krajowej.

Słowa kluczowe: rynek usług TSL, system nośny gospodarki, system wspomagający gospodarkę

DOI: $10.7862 /$ rz.2015.mmr.51

Tekst złożono w redakcji: listopad 2015

Przyjęto do druku: styczeń 2016 